Article

\title{
Effects of Dietary Lysine Levels on Production Performance and Milk Composition of High-Producing Sows during Lactation
}

\author{
Bo Liu ${ }^{1,2}$, Yuanfei Zhou ${ }^{1}{ }^{1}$, Xiong Xia ${ }^{1}$, Chao Wang ${ }^{1}$, Hongkui Wei ${ }^{1}$ and Jian Peng ${ }^{1,3, *}$ \\ 1 Department of Animal Nutrition and Feed Science, College of Animal Science and Technology, Huazhong \\ Agricultural University, Wuhan 430070, China; lhhnliubo@sina.com (B.L.); \\ zhouyuanfei@mail.hzau.edu.cn (Y.Z.); xiong_x@webmail.hzau.edu (X.X.); wangchao1028@163.com (C.W.); \\ weihongkui@mail.hzau.edu.cn (H.W.) \\ 2 Chinwhiz Agribusiness Co., Ltd., Weifang 261000, China \\ 3 The Cooperative Innovation Center for Sustainable Pig Production, Wuhan 430070, China \\ * Correspondence: pengjian@mail.hzau.edu.cn
}

Received: 18 September 2020; Accepted: 16 October 2020; Published: 22 October 2020

Simple Summary: Modern sows need increased nutrient levels to meet their lactation needs with a high litter size. Compared with multiparous sows, primiparous sows need to meet their lactation, growth, and developmental needs. Therefore, ensuring lactation nutrient intake for primiparous sows is important, and it increases the productivity of the entire breeding population. The objective of this experiment was to evaluate the effect of dietary lysine (Lys) levels for lactating primiparous sows on multiple reproductive cycles including piglet performance and milk composition. Results showed that increasing dietary Lys levels in lactation was beneficial for the survival rate of piglets, litter weight, piglet weight, and average daily gain (ADG) at weaning. The dry matter and protein concentrations in milk were increased by the increase in dietary Lys level. Therefore, when implementing strategies for improving reproductive efficiency, increasing the dietary Lys levels during lactation must be considered, especially for primiparous sows.

\begin{abstract}
Modern genotype sows require enhanced nutrition because of their larger body size and higher reproductive performance than 20 years ago. This study aimed to evaluate the effect of dietary Lys on the lactating of primiparous sows and the second lactating period to minimize sow body weight (BW) loss and maximize the survival rate of piglets and litter gain. A total of 160 primiparous Yorkshire sows were randomly allotted to one of four experimental lactation diets. Formulated to contain $0.84 \%, 0.94 \%, 1.04 \%$, and $1.14 \%$ standardized ileal digestibility (SID) Lys and balanced in Met, Thr, Trp, and Val. No dietary effects were found on sow body weight (BW) and backfat thickness (BF) change and feed intake during lactation. However, the Lys intake $(p=0.04)$ of lactation increased linearly with increasing dietary Lys levels. In addition, $1.14 \%$ Lys for primiparous sow and $0.94 \%$ Lys for second parity sow during lactation increased the survival rate $(p=0.04)$, weight $(p=0.04)$, and ADG of piglets at d $21(p=0.03)$. The dietary Lys level did not affect colostrum compositions. However, the dry matter $(p=0.04)$ and protein $(p=0.03)$ in milk increased linearly with the increase in dietary Lys levels, whereas moisture decreased linearly $(p=0.05)$. The level of plasma urea nitrogen (PUN) also increased at $d 21$ of weaning $(p=0.04)$. These results indicate that high-yielding lactating sows required 1.14\% SID Lys during parity 1, and $0.94 \%$ SID Lys during parity 2 to maximize the survival rate of piglets and litter gain, respectively. Moreover, the effects of dietary amino acid (AA) on the production performance of weaning pigs could be mediated through milk composition change.
\end{abstract}

Keywords: lysine; lactation; reproduction performance; primiparous sows 


\section{Introduction}

Modern sows are selected because of their large litter size and milk production [1]. The development of modern lactating sows has also resulted in animals with lessened body fat reserves and decreased appetite [2,3]. Therefore, sows need more nutrients to meet their lactation needs with a high litter size [4].

Compared with multiparous sows, primiparous sows need to meet their lactation, growth, and developmental needs [5]. A previous study reported that body weight (BW) loss was higher at around $12 \%$ during lactation in primiparous sows than in multiparous sows [6]. Feed intake during lactation of sows is often not enough to meet their energy and nutrient needs for maintenance and milk production, especially parity 1 and 2 sows [7]. Research showed that if parity 1 sows lost more than $15 \%$ of their protein mass during lactation, the weight of weaning pigs and the subsequent reproductive efficiency of sows are remarkably reduced [8]. Therefore, lactation nutrition level is more important for primiparous sows than for multiparous sows. This level affects not only the lactation and growth performance of piglets, but also the growth and development of sows, and it further affects the litter number and longevity of sows [9]. Therefore, ensuring optimal nutrition for primiparous sows becomes particularly important to maximize lactation output and long-term productivity.

Sows could achieve and maintain high levels of milk production throughout their productive life if given adequate levels of energy and nutrients. The most critical nutrients for maintaining optimum lifetime milk productivity are energy and amino acids (AA) [10,11]. Lys has been considered the first-limiting AA in corn-soybean meal diets for sows in lactation [12]. An adequate supply of Lys during lactation allows sows to maximize milk production and subsequent reproductive performance [13]. Extensive studies have estimated the total Lys requirements of sows during lactation to be between 37 and $58 \mathrm{~g} / \mathrm{d}$ [14-17]. Recent research has shown that sows required total Lys intakes of $70 \mathrm{~g} / \mathrm{d}$ or $62 \mathrm{~g}$ of standardized ileal digestibility (SID) Lys/d to optimize reproductive and milk production [10]. Moreover, gilts eat $10-15 \%$ less than sows; thus, the percent of SID Lys in lactation must be increased compared to that in mature sow herds [10].

An increased supply of Lys in lactation could allow gilts to consume adequate AA to maximize reproductive performance and ensure body development. Therefore, this experiment aimed to evaluate the effect of dietary Lys levels on the lactation of primiparous sows and the second lactation period to minimize sow BW loss and maximize the survival rate of piglets and litter gain, respectively, and optimize milk composition.

\section{Materials and Methods}

\subsection{Animals, Dietary Treatments, and Housing}

This study was approved by the Huazhong Agricultural University Animal Care and Use Committee (approval number: HAZUSW-2016-039). A total of 160 primiparous Yorkshire sows were randomly allocated into four groups (40 sows each group). On d 110 of pregnancy, they were moved to the farrowing accommodation where they were housed in single farrowing pens. Four farrowing rooms were identical, and each had 40 farrowing pens. Four experimental diets containing different SID Lys levels of $0.84 \%, 0.94 \%, 1.04 \%$, and $1.14 \%$ were provided to primiparous sows from d 110 of pregnancy to weaning (Table 1). Met, Thr, Trp, and Val were used to maintain ratios to Lys that were equal to those of the $0.84 \%$ Lys diet. Litter size was adjusted to $12-14$ pigs per litter at two days after farrowing. Before parturition, all sows were fed with $2.5 \mathrm{~kg}$ of lactation diet per $\mathrm{d}$ from $\mathrm{d} 110$ of pregnancy to parturition. On the day of farrowing, the sows were not fed. On d 2 of farrowing, the sows were fed with $1.5 \mathrm{~kg}$ of diet, which was then successively increased $(3 \mathrm{~kg} / \mathrm{d}$ on $\mathrm{d} 1$ and 2 of lactation, $4.5 \mathrm{~kg} / \mathrm{d}$ on $\mathrm{d} 3$ and 4 of lactation, and ad libitum consumption from d 5 of lactation to weaning). The sows were fed two times daily (at 09:00 and 16:00 h) and allowed ad libitum access to water from parturition until weaning. Then, they were weighed and backfat thickness (BF) was determined within $24 \mathrm{~h}$ after farrowing and at weaning. All sows were fed with the same diet from weaning until the second 
insemination ( $\mathrm{d} 0$ of gestation) and then fed with the same gestation diets (3000 kcal of ME/kg, SID Lys $0.70 \%$ ) in individual stalls until farrowing. During the second reproductive cycle, the sows were fed with the same diets they received during first parity.

Table 1. Ingredients and nutrient compositions of the experimental diets.

\begin{tabular}{|c|c|c|c|c|}
\hline Item & Lys $0.84 \%$ & Lys $0.94 \%$ & Lys $1.04 \%$ & Lys $1.14 \%$ \\
\hline \multicolumn{5}{|l|}{ Feedstuff, \% } \\
\hline Corn & 60.29 & 60.55 & 60.86 & 61.18 \\
\hline Soybean meal & 17.45 & 16.87 & 16.16 & 15.44 \\
\hline DDGS & 5.00 & 5.00 & 5.00 & 5.00 \\
\hline Extruded-soybean & 5.00 & 5.00 & 5.00 & 5.00 \\
\hline wheat bran & 3.00 & 3.00 & 3.00 & 3.00 \\
\hline Fish meal & 2.50 & 2.50 & 2.50 & 2.50 \\
\hline Soybean oil & 1.37 & 1.37 & 1.37 & 1.37 \\
\hline Glucose & 1.50 & 1.50 & 1.50 & 1.50 \\
\hline Yeast cell wall & 0.02 & 0.02 & 0.02 & 0.02 \\
\hline Limestone & 0.95 & 0.96 & 0.96 & 0.96 \\
\hline $\begin{array}{l}\text { Calcium phosphate } \\
\text { (monocalcium) }\end{array}$ & 1.25 & 1.25 & 1.26 & 1.26 \\
\hline Sodium chloride & 0.47 & 0.47 & 0.47 & 0.47 \\
\hline Choline chloride & 0.10 & 0.10 & 0.10 & 0.10 \\
\hline 98\% Lysine & 0.07 & 0.22 & 0.37 & 0.52 \\
\hline DL-Methionine & 0.01 & 0.04 & 0.08 & 0.12 \\
\hline L-Threonine & 0.00 & 0.03 & 0.10 & 0.18 \\
\hline Valine & 0.00 & 0.09 & 0.19 & 0.30 \\
\hline Tryptophan & 0.00 & 0.01 & 0.04 & 0.06 \\
\hline Phytas & 0.02 & 0.02 & 0.02 & 0.02 \\
\hline Premix ${ }^{1}$ & 1.00 & 1.00 & 1.00 & 1.00 \\
\hline Total \% & 100.00 & 100.00 & 100.00 & 100.00 \\
\hline \multicolumn{5}{|c|}{ Composition (calculated) ${ }^{2}$} \\
\hline $\mathrm{NE}, \mathrm{kcal} / \mathrm{kg}$ & 2433 & 2438 & 2445 & 2451 \\
\hline $\mathrm{CP}, \%$ & 18.00 & 18.00 & 18.00 & 18.00 \\
\hline SID Lys, $\%$ & 0.85 & 0.95 & 1.05 & 1.14 \\
\hline SID Met, \% & 0.27 & 0.30 & 0.34 & 0.37 \\
\hline SID Thr, \% & 0.57 & 0.59 & 0.65 & 0.72 \\
\hline SID Trp, $\%$ & 0.16 & 0.19 & 0.22 & 0.25 \\
\hline SID Val, \% & 0.71 & 0.75 & 0.78 & 0.82 \\
\hline $\mathrm{CF}, \%$ & 3.29 & 3.27 & 3.24 & 3.20 \\
\hline $\mathrm{EE}, \%$ & 5.12 & 5.12 & 5.12 & 5.12 \\
\hline $\mathrm{NDF}, \%$ & 11.68 & 11.64 & 11.58 & 11.53 \\
\hline $\mathrm{Ca}, \%$ & 0.85 & 0.85 & 0.85 & 0.85 \\
\hline Available phosphorus, \% & 0.43 & 0.43 & 0.43 & 0.43 \\
\hline
\end{tabular}

${ }^{1}$ Provided per kilogram of the diet: Cu 30 mg; Fe 160 mg; Zn 150 mg; Mn 50 mg; I 0.53 mg; Se 0.53 mg; Co 0.75 mg; Cr $0.22 \mathrm{mg}$; vitamin A $1.271 \times 104 \mathrm{U}$; vitamin D3 $2853 \mathrm{U}$; vitamin E $180 \mathrm{mg}$; vitamin $\mathrm{K}_{3} 3.85 \mathrm{mg}$; vitamin $\mathrm{B}_{1} 1.6 \mathrm{mg}$; vitamin $B_{2} 5.75 \mathrm{mg}$; vitamin $B_{6} 2.88 \mathrm{mg}$; vitamin $B_{12} 0.02 \mathrm{mg}$; nicotinamide $32 \mathrm{mg}$; pantothenic acid $20 \mathrm{mg}$; folic acid $3.2 \mathrm{mg}$; biotin $0.44 \mathrm{mg}$; vitamin C $450 \mathrm{mg}$; choline $1800 \mathrm{mg}$. ${ }^{2}$ Calculated chemical concentrations using values for feed ingredients from National Research Council (2012).

\subsection{Data Collection}

The BW and BF of sows were measured at $24 \mathrm{~h}$ postpartum and $21 \mathrm{~d}$ of lactation. An ultrasound device (Lean-meter, Renco Corp., Minneapolis, MN, US) was used to measure BF at the $\mathrm{P}_{2}$ position (6.5 $\mathrm{cm}$ from the midline over the last rib). The numbers of total born, born alive, stillborn, and mummified piglets were recorded within $24 \mathrm{~h}$ postpartum, and the number of pigs was recorded after cross-fostering and at $21 \mathrm{~d}$ of lactation. Lactation feed intake was recorded weekly. Piglet weight was recorded at $24 \mathrm{~h}$ postpartum; after cross-fostering; and at 7, 14, and $21 \mathrm{~d}$ of lactation. Litter weight was calculated by summing the individual piglet weights. Weaning to estrus interval (WEI) was determined by monitoring for estrus after weaning for $7 \mathrm{~d}$. 


\subsection{Sample Collection and Analysis}

Blood samples were taken from 16 randomly selected sows immediately on the day of parturition after farrowing and at $21 \mathrm{~d}$ of lactation before meal. Blood samples $(10 \mathrm{~mL})$ were collected from the sows through the ear vein. Then, the samples were centrifuged at $3000 \mathrm{~g}$ at $4{ }^{\circ} \mathrm{C}$ for $15 \mathrm{~min}$ (Eppendorf centrifuge 5810R, Hamburg, Germany) to separate the plasma. The sows received injections of $50 \mathrm{IU}$ of oxytocin in the neck at $12 \mathrm{~h}$ postpartum. Colostrum and milk $(30 \mathrm{~mL})$ were collected from the anterior, middle, and posterior teats from one side of the sow by using a $50 \mathrm{~mL}$ centrifuge tube at $24 \mathrm{~h}$ and $14 \mathrm{~d}$ postpartum. The piglets were removed for a period of time before collecting milk and colostrum samples. All samples were stored at $-20{ }^{\circ} \mathrm{C}$ until analysis.

Milk composition was determined using near-infrared reflectance spectroscopy with a Foss Milkoscan FT+ (CombiFT+ 200, Hillerød, Denmark). Before analysis, $5 \mathrm{~mL}$ of thawed milk per sample was aliquoted into a $50 \mathrm{~mL}$ centrifuge tube (sterilized), and $20 \mathrm{~mL}$ distilled water was added to dilute the sample [18]. Plasma urea nitrogen (PUN) level was analyzed using a commercial kit (Nanjing Jiancheng Bioengineering Institute, Nanjing, China) in accordance with the manufacturer's instructions.

\subsection{Calculation and Statistical Analyses}

Calculation and statistical analyses were conducted using SAS software (SAS 9.4, Inst, Inc., Cary, NC, US) with the individual sow as the experimental unit. The PROC MIXED procedure was used in the analyses. Dietary treatment, reproductive cycle, and the interaction between dietary treatment and reproductive cycle were specified as fixed effects. Farrowing room was used as a random effect. In the mixed model, the response variables included litter size, litter weight of piglets born alive and weaning, sow daily feed intake during lactation, WEI, colostrum and milk compositions, and PUN levels. Regression analyses were performed to evaluate the linear and quadratic effects of dietary treatment. Multiple comparisons were conducted when the Analysis of Variance (ANOVA) indicated significant differences. Tukey's test was used in multiple comparisons of means to adjust the $p$ values when using a mixed model procedure for data analysis. Duncan's test was used for one-way ANOVA. Repeated measures ANOVA using the MIXED procedure of SAS was used to examine the responses of piglet performance, sow BW, BF, lactation feed intake, and the data of milk and plasma parameters. Data were presented as means and standard error of mean, and $p<0.05$ was indicated as a significant difference.

\section{Results}

\subsection{Sow Performance}

The BW and BF of sows at farrowing and at weaning did not differ among the dietary treatments (Table 2) and the BW and BF losses during lactation also did not differ. The dietary Lys levels did not affect the feed intake of sows during lactation and WEI. The parity 2 sows had greater BW $(p=0.03)$ and BF $(p<0.01)$ at farrowing and at weaning and BW loss $(p=0.01)$ during the second lactation period than primiparous sows. The feed intake in the second lactation period significantly increased $(p<0.01)$. Lys intake $(p=0.04)$ increased linearly by $37 \%$ from $44.52 \mathrm{~g} / \mathrm{d}$ to $61.20 \mathrm{~g} / \mathrm{d}$ and $39 \%$ from $51.85 \mathrm{~g} / \mathrm{d}$ to $71.94 \mathrm{~g} / \mathrm{d}$ for primiparous and multiparous sows, respectively. In addition, the sows had greater Lys intake $(p<0.01)$ in the second lactation period than in the first. No interaction was observed between dietary treatment and reproduction cycle on sow performance. 
Table 2. Effects of different levels of lysine in lactation diets on sow performance.

\begin{tabular}{|c|c|c|c|c|c|c|c|c|c|c|c|c|c|c|}
\hline \multirow{2}{*}{ Item $^{1}$} & \multicolumn{4}{|c|}{ First Reproductive Cycle } & \multicolumn{4}{|c|}{ Second Reproductive Cycle } & \multirow{2}{*}{ SEM $^{2}$} & \multicolumn{5}{|c|}{$p$-Value ${ }^{3}$} \\
\hline & $0.84 \%$ & $0.94 \%$ & $1.04 \%$ & $1.14 \%$ & $0.84 \%$ & $0.94 \%$ & $1.04 \%$ & $1.14 \%$ & & $\mathbf{L}$ & $\mathbf{Q}$ & Diet & Cycle & Diet $\times$ Cycle \\
\hline No. of sows & 32 & 34 & 31 & 37 & 32 & 34 & 31 & 37 & & & & & & \\
\hline \multicolumn{15}{|l|}{ Sow $\mathrm{BW}^{4}, \mathrm{~kg}$} \\
\hline Parturition & 178.51 & 178.82 & 180.20 & 181.52 & 233.31 & 236.81 & 228.73 & 230.21 & 4.70 & 0.56 & 0.47 & 0.87 & $<0.01$ & 0.19 \\
\hline Weaning & 177.86 & 181.31 & 180.59 & 179.91 & 227.75 & 230.237 & 229.90 & 225.64 & 4.38 & 0.33 & 0.38 & 0.80 & $<0.01$ & 0.78 \\
\hline Loss & -0.65 & 2.49 & 0.38 & -1.61 & -5.56 & -6.58 & 1.16 & -4.58 & 0.26 & 0.75 & 0.12 & 0.37 & 0.03 & 0.28 \\
\hline \multicolumn{15}{|c|}{ Sow backfat thickness, mm } \\
\hline Parturition & 13.76 & 13.78 & 14.35 & 13.61 & 15.06 & 15.44 & 15.29 & 14.74 & 0.42 & 0.62 & 0.57 & 0.18 & $<0.01$ & 0.59 \\
\hline Weaning & 12.70 & 12.81 & 13.32 & 12.24 & 13.94 & 14.08 & 14.26 & 14.02 & 0.42 & 0.55 & 0.63 & 0.24 & $<0.01$ & 0.42 \\
\hline Loss & -1.06 & -0.97 & -1.03 & -1.37 & -1.46 & -1.37 & -1.14 & -0.76 & 0.41 & 0.37 & 0.46 & 0.96 & 0.80 & 0.31 \\
\hline $\mathrm{ADFI}^{5}, \mathrm{~kg} / \mathrm{d}$ & 5.30 & 5.40 & 5.38 & 5.37 & 6.17 & 6.16 & 6.29 & 6.31 & 0.12 & 0.62 & 0.77 & 0.89 & $<0.01$ & 0.33 \\
\hline Lys intake, g/d & 44.52 & 50.72 & 55.94 & 61.20 & 51.85 & 57.88 & 65.40 & 71.94 & 1.61 & 0.04 & 0.43 & 0.03 & $<0.01$ & 0.45 \\
\hline $\mathrm{WEI}^{6}, \mathrm{~d}$ & 7.90 & 6.80 & 7.67 & 7.22 & 6.74 & 5.11 & 4.90 & 5.61 & 0.45 & 0.66 & 0.07 & 0.78 & 0.09 & 0.78 \\
\hline
\end{tabular}

${ }^{1}$ Sow lactation diet contains $0.84 \%, 0.94 \%, 1.04 \%$, and $1.14 \%$ lysine. ${ }^{2}$ Standard error of the mean (SEM). ${ }^{3}$ Linear $(L)$ and quadratic $(Q)$ effects of lysine levels were contrasted. ${ }^{4}$ Body weight (BW). ${ }^{5}$ Average daily feed intake (ADFI). ${ }^{6}$ Weaning to estrus interval (WEI). 


\subsection{Piglet Performance}

The effects of dietary Lys levels in a lactation diet on piglet growth performance during lactation are shown in Table 3. Significant diet $\times$ cycle interactions were observed for the survival rate $(p=0.03)$ and weight $(p=0.04)$ of piglets at $21 \mathrm{~d}$ of lactation. No significant differences were found in litter size (number of total piglets and live piglets at birth, number of piglets at weaning) and piglet weight at birth and after cross-fostering. The survival rate of piglets $(p=0.04)$, litter weight $(p=0.04)$, and average weight of piglet $(p=0.05)$ at $21 \mathrm{~d}$ of lactation and the average daily gain (ADG) of piglet $(p=0.03)$ linearly increased with the increase in dietary Lys levels. Compared with the first lactation period, the second lactation period showed sows with increased litter size $(p<0.01)$, litter weight $(p<0.01)$, and piglet weight $(p<0.01)$ at birth and weaning and increased weight gain $(p<0.01)$. The SID Lys intake for litter weight gain per d $(p=0.03)$ of lactation increased linearly by $20 \%$ from $22.42 \mathrm{~g} / \mathrm{d}$ to $26.89 \mathrm{~g} / \mathrm{d}$ and $16 \%$ from $22.56 \mathrm{~g} / \mathrm{d}$ to $26.07 \mathrm{~g} / \mathrm{d}$ for primiparous and multiparous sows, respectively.

\subsection{Colostrum and Milk Compositions and Plasma Urea Nitrogen Levels}

The fat, lactose, and protein contents were on a dry matter basis. The dietary Lys levels in lactation did not affect the colostrum compositions (Table 4). However, the dry matter $(p=0.04)$ and protein content $(p=0.03)$ in milk increased linearly with the increase in dietary Lys levels, whereas moisture decreased linearly $(p=0.05)$. In addition, different reproductive cycles did not affect the colostrum and milk compositions. PUN level was linearly increased at day 21 of lactation by the increasing dietary Lys levels (Table 5). No interaction was found between dietary treatment and reproduction cycle on the colostrum and milk compositions and PUN levels of sows. 
Table 3. Effects of different levels of lysine in lactation diets on the growth performance of piglets.

\begin{tabular}{|c|c|c|c|c|c|c|c|c|c|c|c|c|c|c|}
\hline \multirow{2}{*}{ Item $^{1}$} & \multicolumn{4}{|c|}{ First Reproductive Cycle } & \multicolumn{4}{|c|}{ Second Reproductive Cycle } & \multirow{2}{*}{ SEM $^{2}$} & \multicolumn{5}{|c|}{$p$-Value ${ }^{3}$} \\
\hline & $0.84 \%$ & $0.94 \%$ & $1.04 \%$ & $1.14 \%$ & $0.84 \%$ & $0.94 \%$ & $1.04 \%$ & $1.14 \%$ & & L & $Q$ & Diet & Cycle & Diet $\times$ Cycle \\
\hline No. of sows & 32 & 34 & 31 & 37 & 32 & 34 & 31 & 37 & & & & & & \\
\hline \multicolumn{15}{|c|}{ Litter size, number/litter } \\
\hline Total born & 13.59 & 13.56 & 13.58 & 13.71 & 15.09 & 16.19 & 15.51 & 16.44 & 0.56 & 0.44 & 0.37 & 0.47 & $<0.01$ & 0.36 \\
\hline Born alive & 11.97 & 12.08 & 12.19 & 12.66 & 14.28 & 15.25 & 14.39 & 15.14 & 0.60 & 0.25 & 0.51 & 0.50 & $<0.01$ & 0.77 \\
\hline $\begin{array}{l}\text { After } \\
\text { cross-fostering }\end{array}$ & 13.53 & 13.86 & 13.71 & 13.26 & 12.80 & 12.83 & 13.09 & 12.79 & 0.29 & 0.78 & 0.66 & 0.30 & $<0.01$ & 0.64 \\
\hline Pigs weaned & 11.09 & 11.11 & 11.03 & 11.45 & 11.56 & 12.08 & 12.10 & 11.91 & 0.23 & 0.53 & 0.59 & 0.97 & $<0.01$ & 0.10 \\
\hline $\begin{array}{l}\text { Survival rate of } \\
\text { piglets } 4, \%\end{array}$ & $82.72^{d}$ & $80.90^{\mathrm{d}}$ & $81.13^{\mathrm{d}}$ & $86.72^{c}$ & $90.61^{b}$ & $94.10^{\mathrm{a}}$ & $93.03^{\mathrm{a}}$ & $93.18^{\mathrm{a}}$ & 2.15 & 0.03 & 0.70 & 0.04 & $<0.01$ & 0.03 \\
\hline \multicolumn{15}{|l|}{ Litter weight, $\mathrm{kg}$} \\
\hline At birth & 16.91 & 16.77 & 16.48 & 17.06 & 20.68 & 20.76 & 20.60 & 20.38 & 0.45 & 0.64 & 0.70 & 0.66 & $<0.01$ & 0.31 \\
\hline $\begin{array}{l}\text { After } \\
\text { cross-fostering }\end{array}$ & 17.26 & 16.68 & 16.69 & 16.80 & 16.92 & 16.59 & 16.41 & 16.10 & 0.57 & 0.73 & 0.81 & 0.46 & 0.18 & 0.77 \\
\hline At day 21 & $55.52^{d}$ & $56.01^{\mathrm{c}, \mathrm{d}}$ & $55.65^{d}$ & $58.80^{\mathrm{c}}$ & $65.38^{b}$ & $70.63^{a}$ & $71.69^{a}$ & $69.92^{\mathrm{a}}$ & 2.16 & 0.77 & 0.79 & 0.04 & $<0.01$ & 0.04 \\
\hline \multicolumn{15}{|c|}{ Piglet mean $\mathrm{BW}^{5}, \mathrm{~kg}$} \\
\hline At birth & 1.29 & 1.25 & 1.24 & 1.25 & 1.32 & 1.32 & 1.31 & 1.40 & 0.05 & 0.65 & 0.84 & 0.39 & $<0.01$ & 0.59 \\
\hline $\begin{array}{l}\text { After } \\
\text { cross-fostering }\end{array}$ & 1.29 & 1.21 & 1.23 & 1.27 & 1.32 & 1.29 & 1.28 & 1.34 & 0.04 & 0.46 & 0.62 & 0.55 & 0.08 & 0.94 \\
\hline At day 21 & 5.00 & 5.01 & 5.03 & 5.15 & 5.68 & 5.85 & 5.92 & 5.88 & 0.15 & 0.04 & 0.25 & 0.05 & $<0.01$ & 0.11 \\
\hline $\begin{array}{l}\text { Piglet ADG }{ }^{6} \\
(\mathrm{~g} / \mathrm{d})\end{array}$ & 179 & 177 & 181 & 185 & 208 & 217 & 221 & 216 & 7.56 & 0.05 & 0.82 & 0.03 & $<0.01$ & 0.44 \\
\hline $\begin{array}{l}\text { Lys intake/Piglet } \\
\text { ADG }(\mathrm{g} / \mathrm{kg} / \mathrm{d})\end{array}$ & 22.42 & 24.79 & 25.02 & 26.89 & 22.56 & 25.45 & 25.84 & 26.07 & 0.24 & 0.04 & 0.15 & 0.03 & $<0.01$ & 0.35 \\
\hline
\end{tabular}

${ }^{1}$ Sow lactation diet contains $0.84 \%, 0.94 \%, 1.04 \%$, and $1.14 \%$ lysine. ${ }^{2}$ Standard error of the mean (SEM). ${ }^{3}$ Linear $(L)$ and quadratic $(Q)$ effects of lysine levels were contrasted. ${ }^{4}$ Pre-weaning survival rate $(\%)=\left(\right.$ number of piglets weaned/number of piglets after cross-fostering) $\times 100 .{ }^{5}$ Body weight (BW). ${ }^{6}$ Average daily gain $\left(\right.$ ADG). ${ }^{\mathrm{a}, \mathrm{b}, \mathrm{c}, \mathrm{d}}$ Different letters indicate significant differences between groups. 
Table 4. Effects of different levels of lysine in lactation diets on the composition of colostrum and milk (dry matter basis).

\begin{tabular}{|c|c|c|c|c|c|c|c|c|c|c|c|c|c|c|}
\hline \multirow{2}{*}{ Item $^{1}$} & \multicolumn{4}{|c|}{ First Reproductive Cycle } & \multicolumn{4}{|c|}{ Second Reproductive Cycle } & \multirow{2}{*}{ SEM $^{2}$} & \multicolumn{5}{|c|}{$p$-Value ${ }^{3}$} \\
\hline & $0.84 \%$ & $0.94 \%$ & $1.04 \%$ & $1.14 \%$ & $0.84 \%$ & $0.94 \%$ & $1.04 \%$ & $1.14 \%$ & & $\mathbf{L}$ & $\mathbf{Q}$ & Diet & Cycle & Diet $\times$ Cycle \\
\hline No. of sows & 16 & 16 & 16 & 16 & 16 & 16 & 16 & 16 & & & & & & \\
\hline \multicolumn{15}{|l|}{ Colostrum } \\
\hline Dry matter, \% & 25.98 & 26.66 & 26.84 & 26.25 & 26.17 & 25.50 & 25.85 & 25.68 & 0.71 & 0.35 & 0.52 & 0.27 & 0.38 & 0.46 \\
\hline Moisture, \% & 74.02 & 73.34 & 73.16 & 73.75 & 73.84 & 74.50 & 74.15 & 74.32 & 0.71 & 0.35 & 0.52 & 0.26 & 0.35 & 0.50 \\
\hline Fat, \% & 18.94 & 18.94 & 18.96 & 19.28 & 19.07 & 19.65 & 19.81 & 19.82 & 0.12 & 0.51 & 0.23 & 0.46 & 0.32 & 0.56 \\
\hline Lactose, $\%$ & 13.51 & 13.65 & 13.04 & 13.52 & 13.57 & 14.43 & 14.12 & 14.37 & 0.13 & 0.14 & 0.46 & 0.15 & 0.20 & 0.34 \\
\hline Protein, \% & 51.42 & 51.13 & 50.60 & 51.47 & 51.74 & 52.33 & 52.80 & 52.58 & 0.16 & 0.40 & 0.57 & 0.25 & 0.24 & 0.28 \\
\hline \multicolumn{15}{|l|}{ Milk } \\
\hline Dry matter, \% & 19.48 & 20.35 & 20.78 & 21.37 & 19.17 & 20.01 & 20.42 & 21.16 & 0.21 & 0.04 & 0.47 & 0.04 & 0.65 & 0.37 \\
\hline Moisture, \% & 80.52 & 79.65 & 79.22 & 78.63 & 80.83 & 79.99 & 79.58 & 78.84 & 0.21 & 0.04 & 0.47 & 0.05 & 0.45 & 0.38 \\
\hline Fat, \% & 36.91 & 36.95 & 37.87 & 36.64 & 36.88 & 36.93 & 36.78 & 37.24 & 0.12 & 0.32 & 0.26 & 0.35 & 0.22 & 0.34 \\
\hline Lactose, $\%$ & 33.88 & 32.68 & 32.05 & 31.82 & 32.32 & 32.63 & 33.01 & 31.90 & 0.16 & 0.16 & 0.23 & 0.25 & 0.24 & 0.45 \\
\hline Protein, $\%$ & 29.57 & 30.47 & 31.91 & 32.05 & 29.32 & 30.88 & 32.42 & 32.52 & 0.17 & 0.03 & 0.46 & 0.03 & 0.35 & 0.43 \\
\hline
\end{tabular}

${ }^{1}$ Sow lactation diet contains $0.84 \%, 0.94 \%, 1.04 \%$, and $1.14 \%$ lysine. ${ }^{2}$ Standard error of the mean (SEM). ${ }^{3}$ Linear $(L)$ and quadratic $(Q)$ effects of lysine levels were contrasted.

Table 5. Effects of different levels of lysine in lactation diets on plasma urea nitrogen (PUN) levels of sows.

\begin{tabular}{|c|c|c|c|c|c|c|c|c|c|c|c|c|c|c|}
\hline \multirow{2}{*}{ Item $^{1}$} & \multicolumn{4}{|c|}{ First Reproductive Cycle } & \multicolumn{4}{|c|}{ Second Reproductive Cycle } & \multirow{2}{*}{ SEM $^{2}$} & \multicolumn{5}{|c|}{$p$-Value ${ }^{3}$} \\
\hline & $0.84 \%$ & $0.94 \%$ & $1.04 \%$ & $1.14 \%$ & $0.84 \%$ & $0.94 \%$ & $1.04 \%$ & $1.14 \%$ & & $\mathbf{L}$ & $\mathbf{Q}$ & Diet & Cycle & Diet $\times$ Cycle \\
\hline No. of sows & 16 & 16 & 16 & 16 & 16 & 16 & 16 & 16 & & & & & & \\
\hline At farrowing & 3.72 & 3.74 & 3.92 & 3.89 & 3.60 & 3.69 & 3.80 & 3.86 & 0.18 & 0.32 & 0.25 & 0.65 & 0.21 & 0.23 \\
\hline At day 21 & 5.21 & 5.36 & 5.71 & 5.81 & 5.13 & 5.35 & 5.59 & 5.83 & 0.21 & 0.04 & 0.37 & 0.05 & 0.42 & 0.36 \\
\hline
\end{tabular}

${ }^{1}$ Sow lactation diet contains $0.84 \%, 0.94 \%, 1.04 \%$, and $1.14 \%$ lysine. ${ }^{2}$ Standard error of the mean $(S E M) .{ }^{3}$ Linear $(L)$ and quadratic $(Q)$ effects of lysine levels were contrasted. 


\section{Discussion}

Lys is the first-limiting amino acid in soybean meal-based diets for lactating sows [19]. Based on the Danish recommendation, $0.84 \%$ of SID Lys is a standard for lactating sows [20]. For primiparous sows, it is necessary to meet the nutritional needs of lactation, and their own growth and development [5]. Therefore, it is crucial to evaluate the Lys requirement for primiparous sows during lactation. In the present study, Lys level did not affect sow lactation BW, BF changes, and feed intake during two lactation periods. Some studies support most of these findings. ADFI and BF changes of sow during lactation, and litter size at weaning were not affected by increases in Lys from 0.80 to $1.06 \%$ [21]. Increasing in Lys from 1.02 to $1.34 \%$ did not affect the BW change, BF change, feed intake, and Lys intake during lactation of primiparous sows [5]. Therefore, the effect of lactation lysine level on sow weight was not consistent, which may be related to the parity, litter size, and feed intake of sows.

In our study, we found that significant diet $\times$ cycle interactions for the survival rate of piglets and weight of piglet at 21 days of lactation. This showed that increasing lysine levels in primiparous sows is beneficial to lactation. Several studies have found that milk yield was lower in primiparous sows than in multiparous sows [6,22], and it is possible that primiparous sows, even when feed intake is high, are more likely to partition additional nutrients into their own growth rather than increasing their milk production $[23,24]$. A study indicated that modern genotype multiparous sows have greater reproductive performance at birth and at weaning than primiparous sows [5]. Another study found that primiparous sows produced litter ADG less than multiparous sows [25]. In addition, our study demonstrates that increasing dietary Lys increased survival rate of piglets, weight of piglet, and ADG of piglet at $21 \mathrm{~d}$ of lactation. These findings were in agreement with the results reported by Chen et al. [26], who evaluated the levels of Lys during lactation. An addition of more than this synthetic AA could decrease preweaning mortality and increase the number of piglets weaned [26]. Similar findings on good litter performance nursed by sows fed higher Lys diets have been reported [27-29]. However, previous studies have reported that sows fed $0.67 \%, 0.86 \%, 1.06 \%$, or $1.25 \%$ of apparent digestible Lys diet during a 17-d lactation did not find any difference in litter performance [15]. In the present study, the number of pigs born and weaned was similar for primiparous and multiparous sows, but greater litter weight at weaning and growth rate was observed in litters nursed by multiparous sows than primiparous sows. Lys intake levels of $0.94 \%$ met the lactation requirements in multiparous sows. However, in our previous research, Lys levels $(0.95 \%$ and $1.10 \%)$ over two consecutive lactations did not affect the average weight at weaning, litter weight at weaning, litter weight gain, and litter growth rate in multiparous sows [30]. A recent study that used a regression equation using published data on Lys requirement of lactating sows predicted a requirement of $27 \mathrm{~g} /$ day of digestible Lys intake for each $1 \mathrm{~kg}$ of litter growth, and $13 \mathrm{~g} /$ day of Lys mobilization from body protein reserves [4]. Therefore, increasing dietary Lys intake can reduce BW loss and body protein mobilization during lactation, especially younger parity sows.

Providing sows with sufficient amounts of nutrients during lactation is crucial for optimal performances from the lactating sows, and consequently the health and growth of the newborn piglets [31,32]. Inadequate nutrient intake during the lactation of sows, however, can reduce milk production and increase sow body weight loss [33]. Furthermore, excessive mobilization of body tissues results in low milk production and delayed return to estrus postweaning [34]. In this study, the clear effect of dietary Lys levels on increased contents of dry matter and protein in milk agreed with the previous observations [5,12]. This could be a key reason for piglets have better lactation performance due to the difference in the sow milk composition with Lys levels increasing during lactation. The milk composition reflected protein and fat of body tissue mobilization in lactating sows [35]. As dietary concentration of the Lys increases, muscle tissue loss decreases, and PUN concentration is increased [14]. In our study, sows fed high-Lys diets had a higher PUN concentration at d 21 of lactation. Similarly, PUN concentration changes were found on by sows fed higher Lys diets $[5,19]$. Furthermore, greater PUN may indicate less protein utilization, excess N, or more 
transamination or deamination [36]. Thus, PUN concentration may be increased if sows were fed more protein or AA than the requirement.

\section{Conclusions}

The Lys levels in lactating sows had no effect on their body condition. However, increasing the dietary Lys levels in lactation was beneficial for the survival rate of the piglets, litter weight, piglet weight, and ADG at weaning. Moreover, the milk protein content increased with the increase in dietary Lys levels, and it may be an important reason for the performance improvement of piglets. Therefore, when implementing strategies for improving reproductive efficiency, increasing the dietary Lys levels during lactation must be considered, especially for primiparous sows.

Author Contributions: J.P., B.L. and H.W. conceptualized and designed the study, X.X. provided field test guidance, Y.Z., X.X. and C.W. acquired the data, B.L., Y.Z. and C.W. analyzed and interpreted the data, B.L., Y.Z. and J.P. drafted and revised the article. All authors have read and agreed to the published version of the manuscript.

Funding: The authors acknowledge the financial support from the National Key Research and Development Project of China (No. 2018YFD0501003, 2017YFD0502004), China Agriculture Research System (No. CARS-36), and the Hubei Provincial Creative Team Project of Agriculture Science and Technology (No. 2007-620).

Acknowledgments: We thank the Shouguang Agribusiness Co. Ltd. for providing the sow feeding facilities.

Conflicts of Interest: The authors declare no conflict of interest.

\section{References}

1. Kraeling, R.R.; Webel, S.K. Current strategies for reproductive management of gilts and sows in North America. J. Anim. Sci. Biotechnol. 2015, 6, 1-14. [CrossRef] [PubMed]

2. Rosero, D.S.; Boyd, R.D.; McCulley, M.; Odle, J.; Van Heugten, E. Essential fatty acid supplementation during lactation is required to maximize the subsequent reproductive performance of the modern sow. Anim. Reprod. Sci. 2016, 168, 151-163. [CrossRef]

3. Zhou, Y.; Xu, T.; Cai, A.; Wu, Y.; Wei, H.; Jiang, S.; Peng, J. Excessive backfat of sows at 109 d of gestation induces lipotoxic placental environment and is associated with declining reproductive performance1. J. Anim. Sci. 2018, 96, 250-257. [CrossRef] [PubMed]

4. Tokach, M.D.; Menegat, M.B.; Gourley, K.M.; Goodband, R.D. Review: Nutrient requirements of the modern high-producing lactating sow, with an emphasis on amino acid requirements. Animal 2019, 13, $2967-2977$. [CrossRef]

5. Yang, Y.; Heo, S.; Jin, Z.; Yun, J.; Choi, J.; Yoon, S.; Park, M.; Yang, B.; Chae, B.-J. Effects of lysine intake during late gestation and lactation on blood metabolites, hormones, milk composition and reproductive performance in primiparous and multiparous sows. Anim. Reprod. Sci. 2009, 112, 199-214. [CrossRef]

6. Shi, M.; Zang, J.; Li, Z.; Shi, C.; Liu, L.; Zhu, Z.; Li, D. Estimation of the optimal standardized ileal digestible lysine requirement for primiparous lactating sows fed diets supplemented with crystalline amino acids. Anim. Sci. J. 2015, 86, 891-896. [CrossRef] [PubMed]

7. Whitney, M.H. Lactating Swine Nutrient Recommendations and Feeding Management. In National Swine Nutrition Guide; Pork Center of Excellence: Des Moines, IA, USA, 2010.

8. Clowes, E.J.; Aherne, F.X.; Foxcroft, G.R.; Baracos, V. Selective protein loss in lactating sows is associated with reduced litter growth and ovarian function. J. Anim. Sci. 2003, 81, 753-764. [CrossRef]

9. Rozeboom, D.W.; Johnston, L.J. Nutritional Aspects of Sow Longevity. Available online: http://old.pork.org/ filelibrary/factsheets/pigfactsheets/newfactsheets/07-01-01g.pdf (accessed on 13 November 2014).

10. Neill, C.; Williams, N.; America, P.N. Milk production and nutritional requirements of modern sows. Lond. Swine Conf. Proc. 2010, 232, 31.

11. Solà-Oriol, D.; Gasa, J. Feeding strategies in pig production: Sows and their piglets. Anim. Feed. Sci. Technol. 2017, 233, 34-52. [CrossRef]

12. Kim, S.; Hurley, W.L.; Wu, G.; Ji, F. Ideal amino acid balance for sows during gestation and lactation1. J. Anim. Sci. 2009, 87, E123-E132. [CrossRef] 
13. Pettigrew, J.E.; Yang, H. Protein nutrition of gestating sows. J. Anim. Sci. 1997, 75, 2723-2730. [CrossRef] [PubMed]

14. King, R.H.; Toner, M.S.; Dove, H.; Atwood, C.S.; Brown, W.G. The response of first-litter sows to dietary protein level during lactation1. J. Anim. Sci. 1993, 71, 2457-2463. [CrossRef] [PubMed]

15. Tokach, M.D.; Pettigrew, J.E.; Crooker, B.A.; Dial, G.D.; Sower, A.F. Quantitative influence of lysine and energy intake on yield of milk components in the primiparous sow. J. Anim. Sci. 1992, 70, 1864-1872. [CrossRef]

16. Touchette, K.J.; Allee, G.L.; Newcomb, M.D.; Boyd, R.D. The lysine requirement of lactating primiparous sows. J. Anim. Sci. 1998, 76, 1091-1097. [CrossRef] [PubMed]

17. Tritton, S.M.; King, R.H.; Campbell, R.G.; Edwards, A.C.; Hughes, P.E. The effects of dietary protein and energy levels of diets offered during lactation on the lactational and subsequent reproductive performance of first-litter sows. Anim. Sci. 1996, 62, 573-579. [CrossRef]

18. Wei, H.; Zhao, X.; Xia, M.; Tan, C.; Gao, J.; Htoo, J.K.; Xu, C.; Peng, J. Different dietary methionine to lysine ratios in the lactation diet: Effects on the performance of sows and their offspring and methionine metabolism in lactating sows. J. Anim. Sci. Biotechnol. 2019, 10, 76. [CrossRef]

19. National Research Council. Nutrient Requirements of Swine, 11th ed.; The National Academies Press: Washington DC, WA, USA, 2012.

20. Tybirk, P.; Sloth, N.M.; Kjeldsen, N.; Shooter, L. Danish Nutrient Requirement Standards [In Danish: Normer for Næringsstoffer], 26th ed.; SEGES Danish Pig Research Centre: Copenhagen, Denmark, 2017.

21. Cooper, D.R.; Patience, J.F.; Zijlstra, R.T.; Rademacher, M. Effect of energy and lysine intake in gestation on sow performance. J. Anim. Sci. 2001, 79, 2367-2377. [CrossRef]

22. King, R.H. Factors that influence milk production in well-fed sows. J. Anim. Sci. 2000, 78, 19-25. [CrossRef]

23. Craig, J.R.; Dunshea, F.; Cottrell, J.J.; Wijesiriwardana, U.A.; Pluske, J.R. Primiparous and Multiparous Sows Have Largely Similar Colostrum and Milk Composition Profiles Throughout Lactation. Animal 2019, 9, 35. [CrossRef]

24. Zak, L.J.; Williams, I.H.; Foxcroft, G.R.; Pluske, J.R.; Cegielski, A.C.; Clowes, E.J.; Aherne, F.X. Feeding lactating primiparous sows to establish three divergent metabolic states: I. Associated endocrine changes and postweaning reproductive performance. J. Anim. Sci. 1998, 76, 1145-1153. [CrossRef]

25. Chen, S.Y.; D'Mello, J.P.F.; Elsley, F.W.H.; Taylor, A.G. Effect of dietary lysine levels on 21-day lactation performance of first-litter sows. Anim. Prod. 1978, 27, 331-344.

26. Cheng, C.; Yen, H.; Hsu, J.; Roan, S.; Wu, J. Effects of Dietary Lysine Supplementation on the Performance of Lactating Sows and Litter Piglets during Different Seasons. Asian-Australas. J. Anim. Sci. 2006, 19, 568-572. [CrossRef]

27. Dourmad, J.Y.; Noblet, J.; Étienne, M. Effect of protein and lysine supply on performance, nitrogen balance, and body composition changes of sows during lactation. J. Anim. Sci. 1998, 76, 542-550. [CrossRef] [PubMed]

28. Gao, K.; Li, G.; Zhu, C.; Wang, L.; Yang, X.; Wen, X.; Wu, Z.; Jiang, Z. Effect of optimizing dietary valine-to-lysine ratio in late gestation or lactation on biochemical indices and performance of lactating primiparous sows. Anim. Feed. Sci. Technol. 2019, 253, 13-21. [CrossRef]

29. Kusina, J.; Pettigrew, J.E.; Sower, A.F.; White, M.E.; Crooker, B.A.; Hathaway, M.R. Effect of protein intake during gestation and lactation on the lactational performance of primiparous sows. J. Anim. Sci. 1999, 77, 931-941. [CrossRef]

30. Huang, F.; Liu, H.; Sun, H.; Peng, J. Effects of lysine and protein intake over two consecutive lactations on lactation and subsequent reproductive performance in multiparous sows. Livest. Sci. 2013, 157, 482-489. [CrossRef]

31. Hojgaard, C.K.; Bruun, T.S.; Theil, P.K. Optimal lysine in diets for high-yielding lactating sows1. J. Anim. Sci. 2019, 97, 4268-4281. [CrossRef]

32. Grela, E.R.; Czech, A.; Kiesz, M.; Wlazło, Ł.; Nowakowicz-Dębek, B. A fermented rapeseed meal additive: Effects on production performance, nutrient digestibility, colostrum immunoglobulin content and microbial flora in sows. Anim. Nutr. 2019, 5, 373-379. [CrossRef]

33. Hong, J.S.; Jin, S.S.; Jung, S.W.; Fang, L.H.; Kim, Y. Evaluation of dry feeding and liquid feeding to lactating sows under high temperature environment. J. Anim. Sci. Technol. 2016, 58, 36. [CrossRef] [PubMed] 
34. Vinsky, M.D.; Novak, S.; Dixon, W.T.; Dyck, M.K.; Foxcroft, G.R. Nutritional restriction in lactating primiparous sows selectively affects female embryo survival and overall litter development. Reprod. Fertil. Dev. 2006, 18, 347-355. [CrossRef]

35. Kim, S.W.; Baker, D.H.; Easter, R.A. Dynamic ideal protein and limiting amino acids for lactating sows: The impact of amino acid mobilization. J. Anim. Sci. 2001, 79, 2356-2366. [CrossRef]

36. Song, M.H.; Baidoo, S.K.; Shurson, G.C.; Whitney, M.H.; Johnston, L.J.; Gallaher, D.D. Dietary effects of distillers dried grains with solubles on performance and milk composition of lactating sows1. J. Anim. Sci. 2010, 88, 3313-3319. [CrossRef]

Publisher's Note: MDPI stays neutral with regard to jurisdictional claims in published maps and institutional affiliations.

(C) 2020 by the authors. Licensee MDPI, Basel, Switzerland. This article is an open access article distributed under the terms and conditions of the Creative Commons Attribution (CC BY) license (http://creativecommons.org/licenses/by/4.0/). 